\title{
A Study of the Effect of Radium upon the Eggs of Ascaris megalocephala univalens.
}

\author{
By \\ Fernandus Payne. \\ (From the Zoological Institute Würzburg.) \\ With plates XIX-XXI. \\ Eingegangen am 25. November 1912.
}

In June and July 1912, Professor Th. Boveri performed the experimental part of this work and made the preparations which were given me for study. I wish to thank him for snggestions and criticisms and for the opportunity of working under his direction. The main purpose of the work has been to follow in more detail than has been done by Perthes and Her'rwig, the history of the chromatin in segmentation.

\section{Experiments.}

The eggs of two different individuals were used in the experiments and I shall speak of these as series No. 1 and No. 2. So far as I can judge, however, the effect has been the same on both. Figs. 5, 27 and 30 are drawings from series No. 1 and the remainder from No. 2. In all cases the eggs were exposed to the radium when the two pronuclei were in the resting stage, and afterward transferred to an oven kept at $37^{\circ} \mathrm{C}$. When development had reached the desired stage they were fixed in an alcohol-acetic mixture $(4$ parts absolute alcohol and 1 part glacial acetic acid), stained in toto in „Salzsäurekarmin*, mounted in glycerine and sealed with balsam. No sections were made.

In series No. 1 , fourteen exposures were made, the time of exposure varying from one to thirteen hours, and the distance of the 
eggs from the radium tube being either two or six.mm. In series No. 2, seventeen exposures were made and all of them excepting the last were six hour exposures at a distance of six $\mathrm{mm}$. The last exposure was sixteen and one-fourth hours at six mm. distance. In the main, I have studied preparations of eggs which were exposed for six hours at a distance of six $\mathrm{mm}$. from the radium tube. This has been done in order to follow, in different stages, the development of eggs which had been treated alike. The exceptions will be pointed out in the description.

\section{Description.}

Paula Hertwig ('11) has shown conclusively, contrary to the conclusions of Perthes ('04), that radium rays have a direct influence on the chromatin of segmenting eggs of Ascaris megalocephala. She has further shown that such rays cause a breaking up of the chromosomes into granules somewhat similar to that which BoverI ('99) has described in the somatic cells. My observations support both of these conclusions. They further support the conclusions of both Perthes and Hertwig that the first cell divisions are regular and that sooner or later abnormalities enter which cause death; also that the achromatic figure appears normal. By a comparison of figures, however, it will be seen that the radium which HerTwig used caused a much greater disturbance in the eggs than that which was used in the present experiments. In fact the chromatin in her experiments has been so greatly disturbed that it bears no resemblance to that of normal cell division.

It should be stated at the beginning that the controls of series No. 2, show the eggs to have been fertilized by the sperm of both univalens and bivalens and that this in all probability accounts for the fact that some eggs contain a larger quantity of chromatin than the others.

Instead of the elongated chromosomes of normal eggs, we find in the first segmentation division (Figs. 1 to 6 ) a variable number of irregular masses and smaller granules. A somewhat similar breaking up of the chromosomes has been described by S'Tevens ('09) in her stndies on the effect of ultra-violet light upon the segmenting eggs of Ascaris megalocephala. Fig. 1 shows a large number of granules, but such figures are exceptional. Usually there are only a few or none at all (Fig. 2). When granules are present, their division seems 
to be regular (Figs. 4, 5 and 6), but the large masses apparently do not divide and may pass to either pole of the spindle (Figs. 3, 4, 5 and 6). In all probability some of these larger masses of chromatin correspond to the cast off ends in the normal somatic cell divisions, bat it is not always possible to point them out as in Figs. 2 and 3. Figs. 1, 2, 3 and 4 are from eggs exposed six hours at a distance of six mm.; Fig. 5 is from an egg exposed six hours at a distance of two mm. and Fig. 6 from an egg exposed sixteen and one-fourth hours at six mm. There seems very little difference in the chromatin of these eggs, although they have been exposed differently. I do not wish to say that the length of the exposure or the distance makes no difference in the degree of injury. Certainly the contrary is the case as is conclusively shown by a study of later stages of development of such eggs. In those eggs exposed for a shorter period of time, normal development goes on to a later stage. However, the degree of injury as shown in the chromatin of the first segmentation division is practically the same.

It is also a significant fact that the chromatin here seems more greatly disturbed than in the later divisions, where it more nearly approaches that of normal cell division. It seems to me the only plausible explanation for this difference is that we have here a more direct effect of the radium on the chromatin and that this effect diminishes to a certain extent in the later stages.

We find here then in the first segmentation division as HerTwig has pointed out, a condition somewhat similar to that which Boverr ('99) has shown to occur in the somatic cells of Ascaris. This is especially true in the anaphase Figs. 4,5 and 6 . In the somatic cells the enlarged ends are thrown out and take no part in nuclear reconstruction. This being the case, $I$ have followed these irregular masses in the radium treated eggs to see whether they also degenerated. My observations indicate that they may or may not take part in the nuclear reconstruction and that they may or may not enter the division figure of the succeeding division. A fact which makes it somewhat difficult to say just what occurs at this time is that instead of a single reconstructed nucleus, we find in most cases several. Whether this multinuclear condition is due to the effect of the radium alone is difficult to say. The controls show only a single reconstructed nucleus, but it is very irregular, elongated and hence not exactly typical (Fig. 7). Professor Boveri tells me that sometimes in normal segmentation, there is a tendency for each chromo- 
some to form a nuclear vesicle. Perhaps here we may have the same thing and the parts of each romosome tend to form a separate nuclear vesicle. Figs. 8, 9 and 10 show masses of chromatin which apparently are in process of nuclear reconstruction. On the other hand in $S_{1}$, Fig. 10, we also find a large mass of chromatin which has taken no part in reconstruction. Cell $P_{1}$ of Fig. 11 is in division and outside the division figure, near the periphery of the cell is a mass of chromatin which certainly has taken no part in nuclear reconstruction and which is also taking no part in division. The same thing is shown in $S_{1}$ of Fig. 12. Fig. 13 gives a case which is undoubtedly a later stage of a cell similar to Fig. 6, where there are two enlarged masses and that both of these have passed to the same pole in the first division. Further these two masses are arranged on the spindle in the succeeding division. Figs. 14, 15 and 16, early anaphases which show the division of the chromatin particles, also show masses of chromatin which form no part of the division figure.

With the exception of Fig. 12, the chromatin particles in $P_{1}$ are larger than in $S_{1}$ and this is true in practically all eggs studied. This difference in the size of the chromatin particles is most certainly due to the fact that the chromatin in the two cells is different. Boveri has shown ('99) that the chromosomes of $S_{1}$ usually break up into smaller particles and the enlarged ends and that the chromosomes of $P_{1}$ remain intact. Sometimes, however, diminution does not occur until a later division. The chromatiu of $S_{1}$ and $P_{1}$ then, under normal conditions usually bebaves differently. Here also under abnormal conditions we find a difference still manifesting itself. The exceptional case of Fig. 12 is no doubt an egg in which under normal conditions, diminution would not have occurred so early and hence $S_{1}$ resembles $P_{1}$. It should also be pointed out that the chromatin in the first segmentation division more elosely resembles the chromatin of $P_{1}$ than $S_{1}$. This similarity is also probably due to the fact that in normal segmentation, the chromosomes in these two divisions behave alike, while in $S_{1}$ the chromosomes usually break up into granules and the enlarged ends.

Since we find here a difference between $P_{1}$ and $S_{1}$, or between the sex and somatic cells, I have attempted to trace the sex cells in later divisions. In the four-cell stage (Figs. 18, 19, 20 and 21) $P_{2}$ is easily recognizable as the chromatin particles are larger than in the other three cells. The same difference manifests itself in the six-cell stage (Figs. 22 and 23). Fig. 24, a seven-cell stage shows 
one cell in division and as the chromatin particles are large it is probably the sex cell. Fig. 25 is a twelve-cell stage with four cells in division. As there is no means of orienting the cells and as the chromatin in the four dividing cells is very much the same, I cannot say which is the sex cell. In the material at my disposal, then, the sex cells cannot be traced with any degree of certainty further than the stages shown in Figs. 22, 23 and 24. The significant fact remains, however, that in the second and third segmentation divisions, in spite of the radium treatment, a constant difference is present between the chromatin of the sex and somatic cells. This constant difference here most decidedly emphasizes the fact bronght out by Boveri ('99) that the chromatin of the sex and somatic cells is different. Whether this difference in the chromatin is bronght about by the action of the cytoplasm of the two cells on the chromatin as Boveri ('10) maintains, is impossible to say.

For the most part, the division into two, four and six cells is a normal process. After this stage, however, irregularities enter sooner or later which canse the death of the egg. These irregularities do not always enter at the same time and the difference is probably due to the fact that all eggs are not injured to the same degree by the radium. Figs. 26 to 30 show some of these irregularities. Whether they are due to the direct effect of the radium on the cytoplasm or whether the effect is indirect coming through the nucleus, is impossible to say and hence needless to discuss. Thinking that perhaps the irregularities might be due to a disturbance of the mechanism of cell division, I have studied the division figure in these irregular dividing cells. However, such division figures (Figs. 26, 27, 28 and 30 ) seem perfectly normal, and if this can be accepted as evidence, a disturbance in the mechanism of cell division cannot be the cause of irregular divisions.

\section{Conclusions.}

My observations support the conclusions of Perthes and HerTwig that the achromatic figure appears perfectly normal; that the first segmentation divisions are regular; and that irregularities enter sooner or later which cause the death of the embryo. They further support the conclusions of HERTwig that the effect of the radium manifests itself in the first segmentation division and that the chromosomes are broken up into irregular masses and granules. In addition to these, 
I find that in the first segmentation division, the enlarged masses of chromatin which are similar to the cast off ends in the somatic cells of normal segmentation, may or may not take part in nuclear reconstruction and the succeeding division; that the chromatin of the first segmentation division is more greatly disturbed than in the divisions which follow. More important, however, than these is the fact that the chromatin of the sex and somatic cells in the second and third segmentation divisions behaves differently. That is, while the chromosomes of both cells break up, the fragments in the sex cells are generally larger.

\section{Bibliography.}

Barlow, Lazarus, and Bonney, Victor, 1909, The Influence of Radio-activity on the Division of Animal Cells. Archives of Middlesex Hospital. Vol. 15. Boveri, TH., 1899, Die Entwicklung von Ascaris megalocephala mit besonderer Rücksicht auf die Kernverhältnisse. Festschrift für C. v. KupFrEr. Jena. 1910, Die Potenzen der Ascaris-Blastomeren bei abgeänderter Furchung. Festschrift zum sechzigsten Geburtstag Richard HerTwigs. München.

HerTwig, O., 1911, Die Radiumkrankheit tierischer Keimzellen. Ein Beitrag zur experimentellen Zengungs- und Vererbungslehre. Arch. f. mikr. Anat. Bd. 77. Abt. II.

HeRTwig, P., 1911, Durch Radiumbestrahlung hervorgerufene Veränderungen in den Kernteilungsfiguren der Eier von Ascaris megalocephala. Arch. f. mikr. Anat. Bd. 77.

Perthes, 1904, Versuche über den Einfluß der Röntgen- und Radiumstrahlen auf die Zellteilung. Deutsche med. Wochenschr.

Stevens, N. M., 1909, The Effect of Ultra-Violet Light upon the Developing Eggs of Ascaris megalocephala. Arch. f. Entw.-Mech. Bd. 27. Heft 4.

\section{Description of Figures. \\ Plates XIX-XXI.}

Figures 5, 27 and 30 are from series No. 1 and the remainder from series No. 2. With the exception of Figs. 5 and 6 all drawings are made from eggs exposed six hours at a distance of six mm. Fig. 5 is from an egg exposed six hours at a distance of two mm. and Fig. 6 from an egg exposed sixteen and one-fourth hours at six $\mathrm{mm}$. The chromatin particles are drawn as accurately as possible but the spindle is diagrammatic. The lettering of the cells is the same as that used by Boveri ('99).

Fig. 1. Metaphase, pole view, first segmentation division.

Fig. 2. Metaphase, pole view, first segmentation division.

Fig. 3. Anaphase, side view, first segmentation division.

Fig. 4. Anaphase, side view, first segmentation division.

Fig. 5. Anaphase, side view, first segmentation division. 


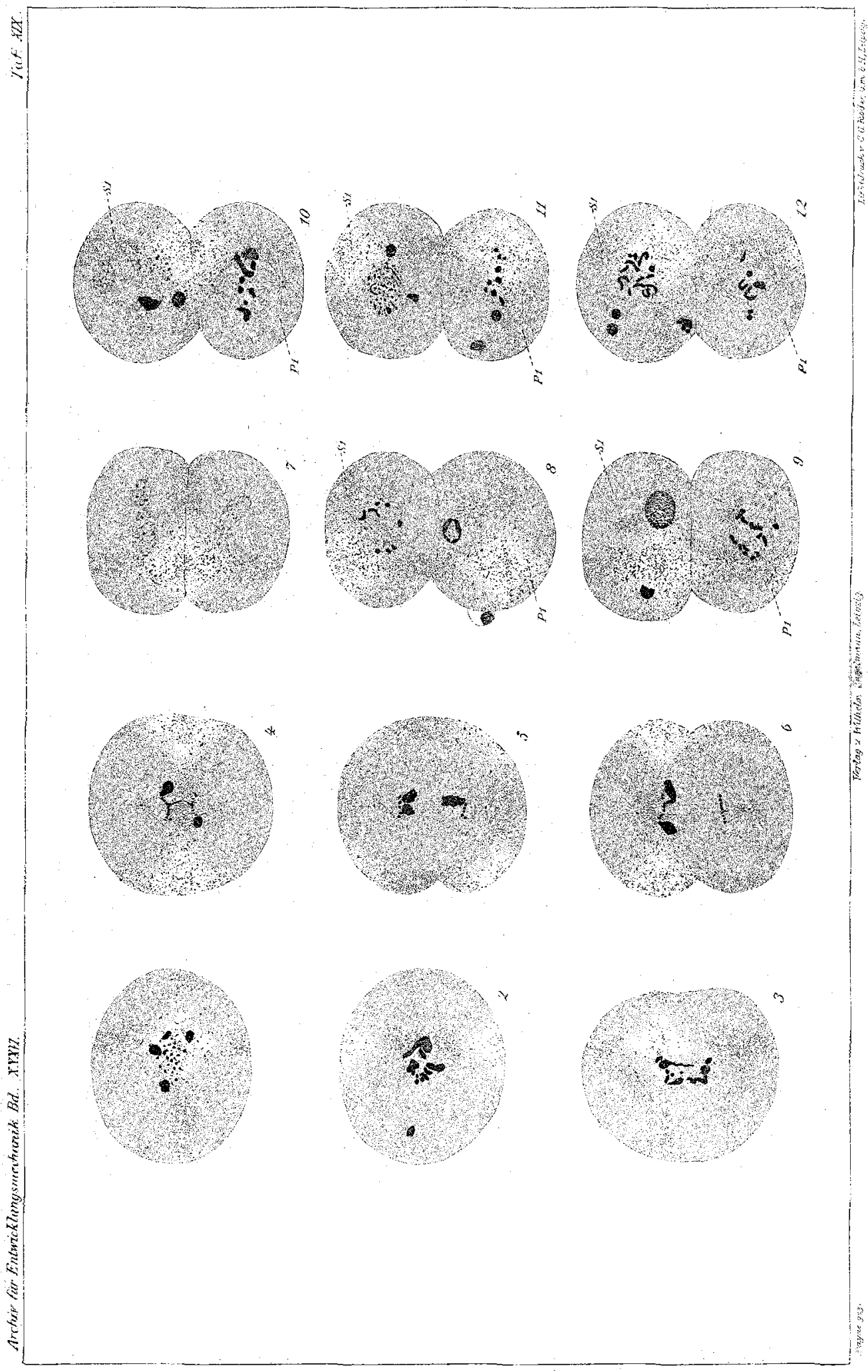




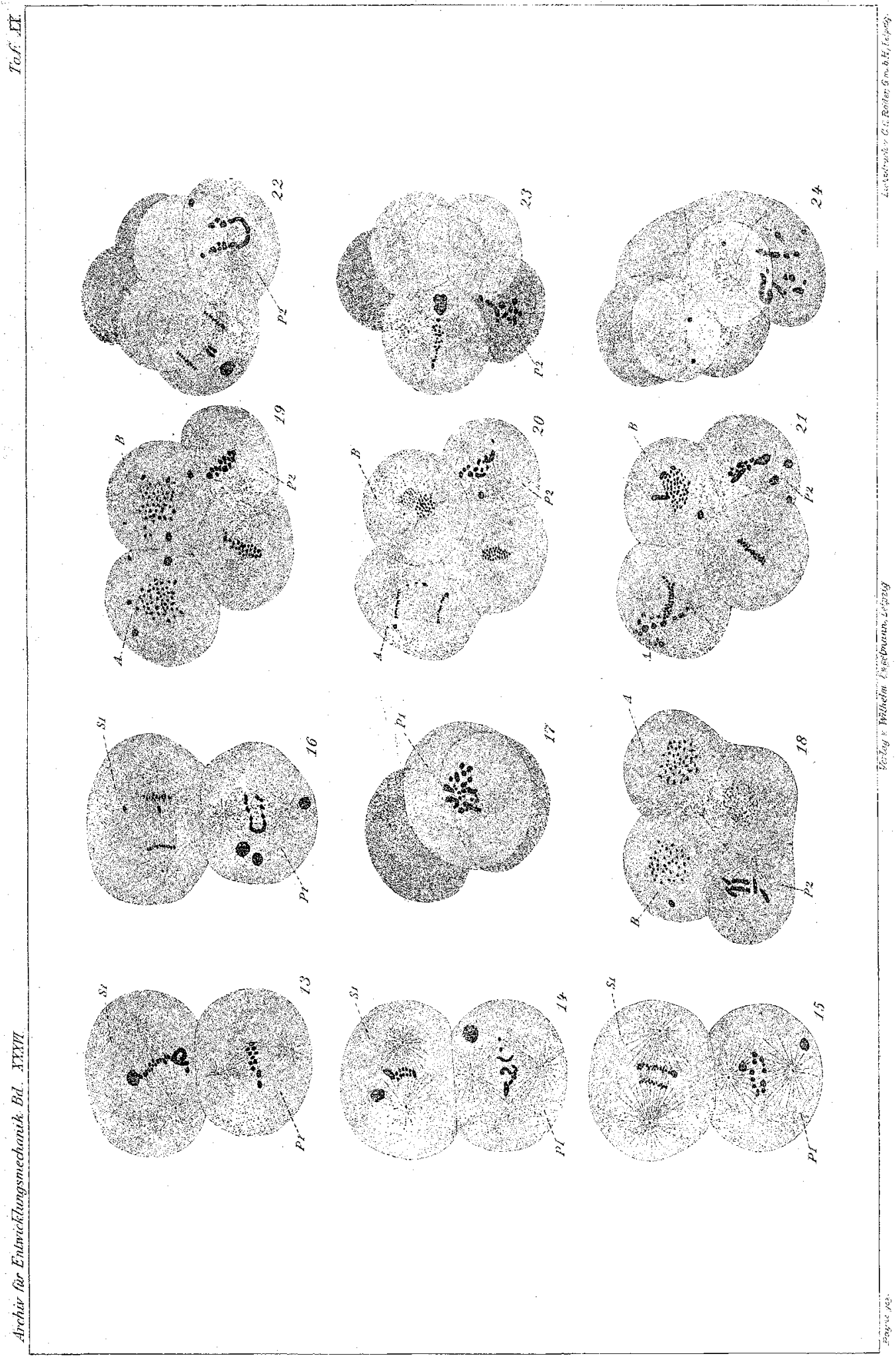



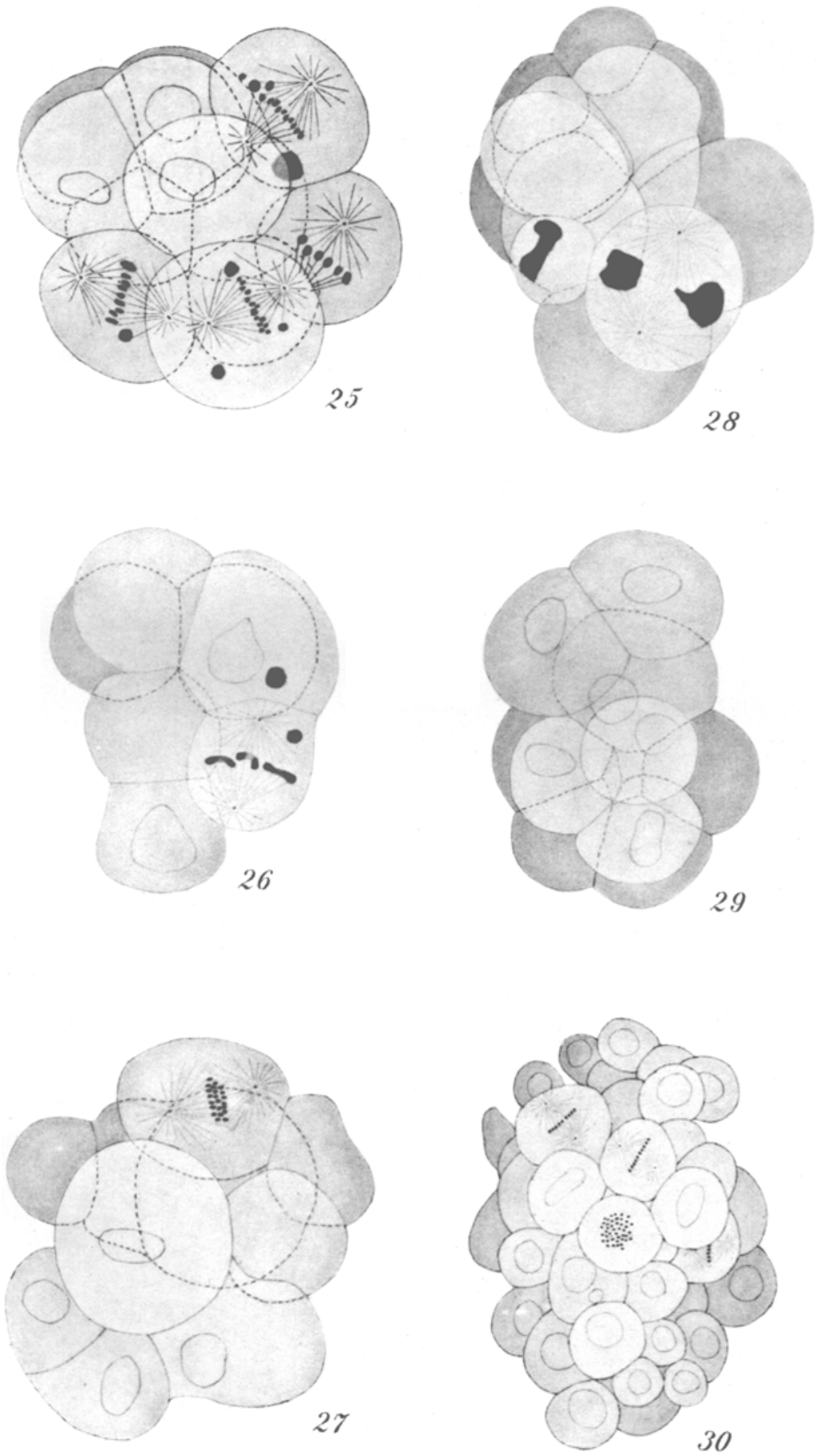
Fig. 6. Anaphase, side view, first segmentation division.

Fig. 7. Two-cell stage showing irregular reconstructed nuclei in the controls.

Fig. 8. Two-cell stage, showing multinuclear condition in $P_{1}$ and reconstructed nucleus from a large mass of chromatin.

Fig. 9. Two-cell stage, showing multinuclear condition in $S_{1}$ and reconstructed nucleas from a large mass of chromatin.

Fig. 10. Two-cell stage, showing multinuclear condition in $S_{1}$; a large mass of chromatin taking part in reconstruction and a second mass which is not taking part in reconstruction.

Fig. 11. Two-cell stage; both cells in metaphase; small grannles in $S_{1}$.

Fig. 12. Two-cell stage; both cells in metaphase; chromatin in large particles in $S_{1}$.

Fig. 13. Two-cell stage; both cells in metaphase.

Fig. 14. Two-cell stage; chromatin in $P_{1}$ in metaphase, in $S_{1}$ in anaphase. Both cells show a single large mass of chromatin outside the division figure.

Fig. 15. Two-cell stage; both cells in anaphase.

Fig. 16. Two-cell stage; both cells in anaphase.

Fig. 17. Three-cell stage; the chromatin of $P_{1}$ in metaphase, pole view.

Fig. 18. Four-cell stage; three cells in division; shows difference in size of chromatin particles in $P_{2}$ and $A$ and $B$.

Fig. 19. Four-cell stage; four cells in division.

Fig. 20. Four-cell stage; four cells in division.

Fig. 21. Four-cell stage; four cells in division.

Fig. 22. Six-cell stage; two cells in division.

Fig. 23. Six-cell stage; two cells in division; cells differently arranged than in Fig. 22.

Fig. 24. Seven-cell stage; one cell, with large chromatin particles, in division.

Fig. 25. Twelve-cell stage; four cells in division; impossible to say which is sex-cell.

Fig. 26. Shows irregular cleavage; one cell in division and achromatic figure appears normal.

Fig. 27. Shows irregular cleavage; achromatic figure normal.

Fig. 28. Shows irregular cleavage; achromatic figure normal.

Fig. 29. Shows irregular cleavage.

Fig. 30. Shows irregular cleavage; achromatic figures normal. 